\title{
Cytotoxic and anti-inflammatory disulfide compounds from the fruiting bodies of Boletus pseudocalopus
}

\author{
Chung Sub Kim ${ }^{1}$, Eunjung Moon ${ }^{2}$, Sang Un $\mathrm{Choi}^{3}$, Sun Yeou Kim² ${ }^{2}$ Kang Ro Lee ${ }^{1}$ and Ki Hyun Kim ${ }^{1}$ \\ The Journal of Antibiotics (2015) 68, 414-416; doi:10.1038/ja.2015.2; published online 28 January 2015
}

Boletus pseudocalopus (Boletaceae) is an inedible mushroom that mainly causes gastrointestinal irritation, and is widely distributed in Korea and Japan. ${ }^{1}$ It is recognized by its yellow fruiting bodies and the blue staining when the fruit bodies are cut or brushed. ${ }^{1,2}$ A previous phytochemical study of this mushroom reported the isolation of cytotoxic grifolin derivatives. ${ }^{2}$ During our screening for new cytotoxic metabolites from Korean wild mushrooms, it was found that the $\mathrm{MeOH}$ extract of B. pseudocalopus showed significant cytotoxicity against three human tumor cell lines (A549, Hs746T and H3122). ${ }^{3}$ Three new cytotoxic fatty acid esters, calopusins A-C, were isolated from its $\mathrm{CHCl}_{3}$-soluble fraction by the bioassay-guided isolation, and were recently reported. ${ }^{3}$ As a part of our continuing efforts to study the bioactive constituents of the $\mathrm{MeOH}$ extract of B. pseudocalopus, we have investigated its $n$ - $\mathrm{BuOH}$-soluble fraction in the search for structurally interesting and bioactive metabolites. Repeated column chromatographic separation of the $n$ - $\mathrm{BuOH}$-soluble fraction of the $\mathrm{MeOH}$ extract resulted in the isolation of two disulfide compounds including a new compound, 3-methylbuthyl hydrodisulfide (1) and phenylethyl hydrodisulfide (2), which was previously reported but only as a synthetic product, ${ }^{4}$ together with three known polar compounds including erythritol $(3),{ }^{5}$ arabinitol $(4)^{5}$ and uracil $(5)^{6}$ (Figure 1). The structures of $\mathbf{1}$ and $\mathbf{2}$ were elucidated on the basis of $1 \mathrm{D}$ and 2D NMR spectroscopic data analysis, and the known compounds 3-5 were identified by comparison of the physical and spectroscopic data with the values in the literature. Here, we describe the isolation and structural elucidation of 1 and 2 , as well as the biological activities of the isolates $\mathbf{1 - 5}$.

The fresh fruiting bodies of B. pseudocalopus were collected at Mt. Gaya, Hapcheon-Gun of Gyeongsangnam-do, Korea, in August 2006. The mushroom was authenticated by one of the authors (K.R.L.). The air-dried and powdered fruiting bodies of B. pseudocalopus $(139 \mathrm{~g}$ ) were extracted twice with $80 \%$ aqueous $\mathrm{MeOH}$ (each $1.51 \times 2$ days) at room temperature and filtered. The filtrate was concentrated under vacuum to give a crude $\mathrm{MeOH}$ extract $(10 \mathrm{~g})$, which was partitioned with $n$-hexane, $\mathrm{CHCl}_{3}$ and $n$-BuOH by using $\mathrm{H}_{2} \mathrm{O}$, yielding 600,700 and $2100 \mathrm{mg}$ of residues, respectively.
The $\mathrm{CHCl}_{3}$-soluble fraction was investigated in a previous study ${ }^{3}$ and the main fraction, the $n$ - $\mathrm{BuOH}$-soluble fraction, was selected for the current phytochemical investigation. The $n$ - $\mathrm{BuOH}$-soluble fraction (2 g) was separated over a silica gel (50 g, 230-400 mesh, Merck, Darmstadt, Germany) open column chromatography with $\mathrm{CHCl}_{3-}$ $\mathrm{MeOH}-\mathrm{H}_{2} \mathrm{O}$ (16:7:1) to yield eight fractions (B1-B8). Fraction B2 $\left(150 \mathrm{mg}\right.$ ) was purified by $\mathrm{RP}_{-} \mathrm{C}_{18}$ semi-preparative HPLC (Econosil RP-18 column, Alltech, Nicholasville, KY, USA, $10 \mu \mathrm{m}, 250 \mathrm{~mm} \times 10$ $\mathrm{mm}$ i.d.) using a solvent of $\mathrm{MeOH}-\mathrm{H}_{2} \mathrm{O}$ (85:15) to yield compound 5 $(4 \mathrm{mg})$. Fraction B4 $(240 \mathrm{mg})$ was purified by normal-phase semipreparative HPLC (Apollo Silica column, Alltech, $5 \mu \mathrm{m}, 250 \mathrm{~mm} \times 10$ mm i.d.) using a solvent system of $\mathrm{CHCl}_{3}-\mathrm{MeOH}$ (4:1) to afford compounds $2(8 \mathrm{mg})$ and $3(6 \mathrm{mg})$. Compound $4(30 \mathrm{mg})$ was isolated from fraction $\mathrm{B} 6(410 \mathrm{mg})$ by the purification of $\mathrm{RP}^{-\mathrm{C}_{18}}$ semipreparative HPLC (Econosil RP-18 column) with $\mathrm{MeOH}-\mathrm{H}_{2} \mathrm{O}$ (85:15). Finally, fraction B7 $(270 \mathrm{mg})$ was subjected to passage over a Waters Sep-Pak Vac 6 cc (Milford, MA, USA) with a solvent of $\mathrm{CHCl}_{3}-\mathrm{MeOH}-\mathrm{H}_{2} \mathrm{O}$ (9:5:1) to obtain the new compound 1 (24 mg).

The physico-chemical properties of compound $\mathbf{1}$ are summarized in Table 1. The molecular formula of 1 was determined to be $\mathrm{C}_{5} \mathrm{H}_{12} \mathrm{~S}_{2}$ from the $[\mathrm{M}+\mathrm{Na}]^{+}$peak at $\mathrm{m} / z 159.0273$ (calcd. for $\mathrm{C}_{5} \mathrm{H}_{12} \mathrm{~S}_{2} \mathrm{Na}$, 159.0278) in the positive-ion high resolution (HR)-ESIMS spectrum. The structure of compound 1 was mainly elucidated by analysis of NMR spectra including 2D NMR. The ${ }^{1} \mathrm{H}$ NMR spectrum (Table 2) of 1 showed characteristic signals for two methylene protons at $\delta_{\mathrm{H}} 2.93$ $(2 \mathrm{H}, \mathrm{t}, J=7.0 \mathrm{~Hz})$ and $1.54(2 \mathrm{H}, \mathrm{q}, J=7.0 \mathrm{~Hz})$, a methine proton at $\delta_{\mathrm{H}}$ $1.67(1 \mathrm{H}, \mathrm{m})$ and two methyl groups at $\delta_{\mathrm{H}} 0.96(6 \mathrm{H}, \mathrm{d}, J=7.0 \mathrm{~Hz})$. The ${ }^{13} \mathrm{C}$ NMR (Table 2) and DEPT spectra displayed two methylene carbons at $\delta_{\mathrm{C}} 37.9$ and 36.2 , a methine carbon at $\delta_{\mathrm{C}} 25.6$ and two overlap methyl carbons at $\delta_{\mathrm{C}} 21.3$. Interpretation of the HMQC data allowed all single bond proton and carbon correlations to be assigned (Table 1). An analysis of the ${ }^{1} \mathrm{H}-{ }^{1} \mathrm{H}$ COSY and HMBC spectra for 1 led to be assigned the gross structure seen in Figure 2. The cross-peaks between $\mathrm{H}-1\left(\delta_{\mathrm{H}} 2.93\right)$ and $\mathrm{H}-2\left(\delta_{\mathrm{H}} 1.54\right), \mathrm{H}-2\left(\delta_{\mathrm{H}} 1.54\right)$ and $\mathrm{H}-3$ $\left(\delta_{\mathrm{H}} 1.67\right), \mathrm{H}-3\left(\delta_{\mathrm{H}} 1.67\right)$ and $\mathrm{H}-4\left(\delta_{\mathrm{H}} 0.96\right)$, and $\mathrm{H}-3\left(\delta_{\mathrm{H}} 1.67\right)$ and

${ }^{1}$ Natural Product Research Laboratory, School of Pharmacy, Sungkyunkwan University, Suwon, Korea; ${ }^{2}$ College of Pharmacy, Gachon University, Incheon, Korea and ${ }^{3}$ Bio-organic Science Division, Pharmacology Research Center, Korea Research Institute of Chemical Technology, Deajeon, Korea

Correspondence: Professor Dr KH Kim, Natural Product Research Laboratory, School of Pharmacy, Sungkyunkwan University, 300 Cheoncheon-dong, Jangan-gu, Suwon 440-746, Korea.

E-mail: khkim83@skku.edu

Received 3 November 2014; revised 5 December 2014; accepted 22 December 2014; published online 28 January 2015 
$\mathrm{H}-5\left(\delta_{\mathrm{H}} 0.96\right)$ were observed in the ${ }^{1} \mathrm{H}-{ }^{1} \mathrm{H}$ COSY spectrum (Figure 2). It allowed us to establish the isopentane unit, which was further supported by key HMBC correlations from H-1 to C-3 $\left(\delta_{\mathrm{C}} 25.6\right)$ and $\mathrm{H}-4$ and $\mathrm{H}-5$ to $\mathrm{C}-2\left(\delta_{\mathrm{C}} 36.2\right)$. The NMR spectra of 1 were generally similar to those of 3-methyl-1-butanol, ${ }^{7}$ but the apparent differences were the signals attributable to $\mathrm{C}-1$ and $\mathrm{C}-2$. In the case of 3-methyl-1butanol, ${ }^{7}$ the substituent of the hydroxyl group $(\mathrm{OH})$ at $\mathrm{C}-1$ in the isopentane unit led to downfield shift of the signals $\left[\delta_{\mathrm{H}} 3.58(\mathrm{H}-1), \delta_{\mathrm{C}}\right.$ $\left.61.2(\mathrm{C}-1) ; \delta_{\mathrm{H}} 1.42(\mathrm{H}-2), \delta_{\mathrm{C}} 42.6(\mathrm{C}-2)\right]$ for $\mathrm{C}-1$ and $\mathrm{C}-2$, compared with those $\left[\delta_{\mathrm{H}} 2.93(\mathrm{H}-1), \delta_{\mathrm{C}} 37.9(\mathrm{C}-1) ; \delta_{\mathrm{H}} 1.54(\mathrm{H}-2), \delta_{\mathrm{C}} 36.2\right.$ (C-2)] of 1 . The characteristic signals for C-1 and C-2 allowed us to expect the substituent at $\mathrm{C}-1$ to be an amine $\left(\mathrm{NH}_{2}\right)$ or thiol group (SH). However, a survey of the literature revealed that compound 1 does not have the expected substituents at C-1 when compared with<smiles>CC(C)CCSS</smiles><smiles>SSCCc1ccccc1</smiles><smiles>OC[C@H](O)[C@H](O)CO</smiles><smiles>OC[C@@H](O)C(O)[C@H](O)CO</smiles>

4<smiles>O=c1cc[nH]c(=O)[nH]1</smiles>

5
Figure 1 Structures of compounds $\mathbf{1 - 5}$.

Table 1 Physico-chemical properties of compounds 1 and 2

\begin{tabular}{lcc} 
& Compound $\mathbf{1}$ & Compound 2 \\
\hline Appearance & Colorless gum & Colorless gum \\
Molecular formula & $\mathrm{C}_{5} \mathrm{H}_{12} \mathrm{~S}_{2}$ & $\mathrm{C}_{8} \mathrm{H}_{10} \mathrm{~S}_{2}$ \\
Molecular weight & 136 & 170 \\
HR-ESIMS $\mathrm{m} / z$ & {$[\mathrm{M}+\mathrm{Na}]^{+}$} & {$[\mathrm{M}+\mathrm{Na}]^{+}$} \\
Calcd & $159.0278\left(\mathrm{C}_{5} \mathrm{H}_{12} \mathrm{~S}_{2} \mathrm{Na}\right)$ & $193.0122\left(\mathrm{C}_{8} \mathrm{H}_{10} \mathrm{~S}_{2} \mathrm{Na}\right)$ \\
Found & 159.0273 & 193.0125 \\
UV $(\mathrm{MeOH}) \lambda_{\max }(\log \varepsilon)$ & & $263(2.4), 217(3.9)$ \\
IR $(\mathrm{KBr}) \nu_{\max }\left(\mathrm{cm}^{-1}\right)$ & $2947,2935,2494$, & $2949,2937,2502,1661$, \\
& 1451 & 1456 \\
\hline
\end{tabular}

the NMR data of the related compounds. ${ }^{8,9}$ The NMR data of 3 -methybutylamine displayed the resonances of C-1 $\left(\delta_{\mathrm{C}} 40.6\right)$ and $\mathrm{C}-2\left(\delta_{\mathrm{C}} 43.7\right)$ in the ${ }^{13} \mathrm{C}$ NMR spectrum, ${ }^{8}$ whereas the NMR data of butane-1-thiol showed a similar chemical shift of C-2 $\left(\delta_{\mathrm{C}} 37.1\right)$ to

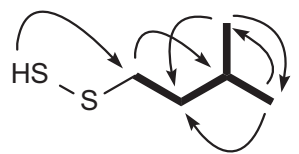

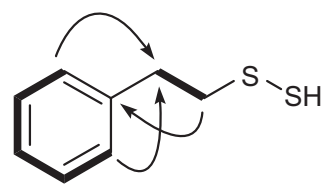

2
Figure 2 Key COSY (bold) and HMBC (arrow) correlations of $\mathbf{1}$ and $\mathbf{2}$.

Table 3 Antiproliferative activities of compounds 1-2 against four cultured human cancer cell lines

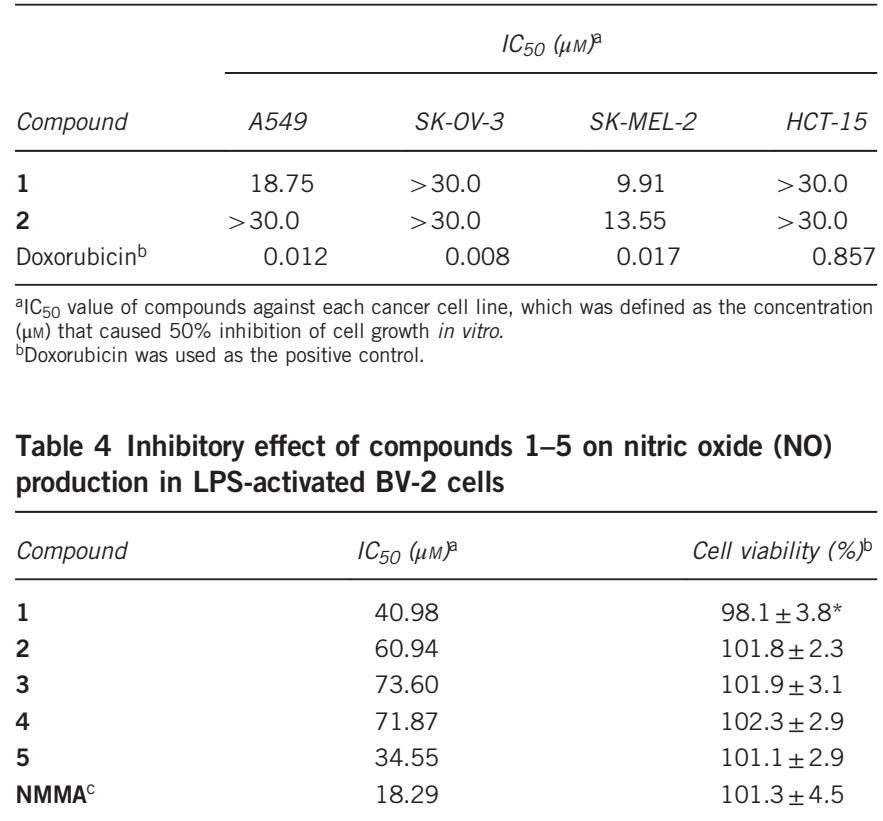

Abbreviation: LPS, lipopolysaccharide.

Results are averages of three independent experiments, and data are expressed as mean \pm s.d. $\left({ }^{*} P\right.$-value $\left.<0.05\right)$.

${ }^{a} \mathrm{C}_{50}$ value of each compound was defined as the concentration $(\mu \mathrm{M})$ that caused $50 \%$ inhibition of NO production in LPS-activated BV-2 cells.

Cell viability after treatment with $20 \mu \mathrm{m}$ of each compound and LPS is expressed as a percentage (\%) of the group treated with LPS only. NMMA was the positive control.

Table 2 NMR spectroscopic data for compounds 1 and $2^{\mathrm{a}}$

\begin{tabular}{|c|c|c|c|c|c|c|c|c|}
\hline \multirow[b]{2}{*}{ Position } & \multicolumn{5}{|c|}{1} & \multicolumn{3}{|c|}{2} \\
\hline & $\delta_{H}\left(C D_{3} O D\right)$ & $\delta_{C}\left(C D_{3} O D\right)$ & $\delta_{H}\left(\mathrm{CDCl}_{3}\right)$ & $\delta_{C}\left(C D C l_{3}\right)$ & $H M B C$ & $\delta_{H}\left(C D_{3} O D\right)$ & $\delta_{C}\left(C D_{3} O D\right)$ & $H M B C$ \\
\hline 1 & 2.93 t (7.0) & $37.9 \mathrm{t}$ & 3.00 t (7.0) & $38.4 \mathrm{t}$ & C-2, 3 & & $136.6 \mathrm{~s}$ & \\
\hline 2 & 1.54 q (7.0) & $36.2 \mathrm{t}$ & 1.67 q (7.0) & $36.3 t$ & C- $1,3,4,5$ & $7.28 \mathrm{~m}$ & $128.5 \mathrm{~d}$ & $C-4,6,7$ \\
\hline 3 & $1.67 \mathrm{~m}$ & $25.6 \mathrm{~d}$ & $1.70 \mathrm{~m}$ & $25.7 d$ & C- $1,2,4,5$ & $7.34 \mathrm{td}(8.0,1.5)$ & $128.8 \mathrm{~d}$ & C-1, 5 \\
\hline 4 & $0.96 \mathrm{~d}(7.0)$ & $21.3 \mathrm{q}$ & $0.92 \mathrm{~d}(7.0)$ & $22.1 \mathrm{q}$ & $\mathrm{C}-2,3,5$ & $7.25 \mathrm{~m}$ & $127.1 \mathrm{~d}$ & C-2, 6 \\
\hline 5 & $0.96 \mathrm{~d}(7.0)$ & $21.3 \mathrm{q}$ & 0.92 d (7.0) & $22.1 \mathrm{q}$ & $C-2,3,4$ & $7.34 \mathrm{td}(8.0,1.5)$ & $128.8 \mathrm{~d}$ & C-1, 3 \\
\hline 6 & & & & & & $7.28 \mathrm{~m}$ & $128.5 \mathrm{~d}$ & $C-2,4,7$ \\
\hline 7 & & & & & & 2.95 t (7.5) & $33.3 \mathrm{t}$ & $C-1,2,6,8$ \\
\hline 8 & & & & & & 3.17 t (7.5) & $40.7 \mathrm{t}$ & C-1, 7 \\
\hline SSH & & & $3.24 \mathrm{~s}$ & & C-1 & & & \\
\hline
\end{tabular}

${ }^{{ }^{1} \mathrm{H}}$ and ${ }^{13} \mathrm{C}$ NMR data were recorded at 500 and $125 \mathrm{MHz}$, respectively. Coupling constants (in $\mathrm{Hz}$ ) are given in parentheses. 
the corresponding one of 1 , but upfield shifted resonance of C-1 $\left(\delta_{\mathrm{C}}\right.$ 24.6). ${ }^{9}$ On the other hand, the ${ }^{1} \mathrm{H}$ NMR spectrum of 1 was found to be very similar to that of pentyl hydrodisulfide, ${ }^{10}$ although the acidic proton of SSH was not detected owing to usage of the NMR solvent of $\mathrm{CD}_{3} \mathrm{OD}$. The existence of the hydrodisulfide group ( $\mathrm{SSH}$ ) could be suggested by the IR spectrum of 1 exhibiting IR absorption at $2494 \mathrm{~cm}^{-1}$ attributed to SSH. Furthermore, the presence of the hydrodisulfide group was confirmed on the basis of the molecular formula, $\mathrm{C}_{5} \mathrm{H}_{12} \mathrm{~S}_{2}$ established by the HR-ESIMS data. To identify the acidic proton of SSH in compound $1,{ }^{1} \mathrm{H}$ NMR spectrum (Table 2) of 1 was additionally measured in $\mathrm{CDCl}_{3}$ where the acidic proton of $\mathrm{SSH}$ was observed at $\delta_{\mathrm{H}} 3.24(1 \mathrm{H}, \mathrm{s})$. The proton signal of SSH showed HMBC correlation with C-1 $\left(\delta_{\mathrm{C}} 38.4\right)$. Thus, the structure of 1 was elucidated as 3-methylbuthyl hydrodisulfide, and is shown in Figure 1.

Compound 2 was obtained as a colorless gum, and the molecular formula $\mathrm{C}_{8} \mathrm{H}_{10} \mathrm{~S}_{2}$ was established by HR-ESIMS. The physico-chemical properties of $\mathbf{2}$ are summarized in Table 1. The structure of compound 2 was determined by analysis of NMR spectra including 2D NMR (Figure 2), where characteristic signals for the phenylethyl unit were clearly assigned. The presence of a hydrodisulfide group was also confirmed by the downfield shifted signals of C-7 and C-8 and the IR absorption at $2502 \mathrm{~cm}^{-1}$, together with the molecular formula, $\mathrm{C}_{8} \mathrm{H}_{10} \mathrm{~S}_{2}$ established by the HR-ESIMS data. Thus, the structure of 2 was determined as phenylethyl hydrodisulfide (2), which was previously reported but only as a synthetic product. ${ }^{4}$ Full NMR data assignments of 2 were reported in this study for the first time (Table 2).

The antiproliferative activities of compounds $\mathbf{1} \mathbf{- 5}$ were evaluated by determining their inhibitory effects on four human tumor cell lines, namely A549 (non-small cell lung carcinoma), SK-OV-3 (ovary malignant ascites), SK-MEL-2 (skin melanoma) and HCT-15 (colon adenocarcinoma) using the SRB bioassay. ${ }^{11}$ After continuous exposure to the compounds for $48 \mathrm{~h}$, compound 1 showed antiproliferative activity against A549 and SK-MEL-2 cells with IC $_{50}$ values of 18.75 and $9.91 \mu \mathrm{M}$, respectively, and compound 2 exhibited the activity against the SK-MEL-2 cell line with an $\mathrm{IC}_{50}$ value of $13.55 \mu \mathrm{m}$, but the other compounds (3-5) were inactive $\left(\mathrm{IC}_{50}>30.0 \mu \mathrm{M}\right)$ (Table 3 ).

In addition, the anti-inflammatory activities of compounds 1-5 were evaluated by measuring the produced nitric oxide (NO) levels in lipopolysaccharide-activated microglia BV-2 cells. ${ }^{12}$ After $24 \mathrm{~h}$ incubation, compounds 1 and 2 displayed an anti-inflammatory effect by inhibiting NO levels with $\mathrm{IC}_{50}$ values of 40.98 and $60.94 \mu \mathrm{M}$, respectively, in lipopolysaccharide-stimulated BV-2 cells without cytotoxicity, while compound $\mathbf{5}$ significantly exhibited the inhibitory activity with an $\mathrm{IC}_{50}$ of $34.55 \mu \mathrm{M}$ (Table 4 ).

Disulfide compounds and other structurally related compounds have been reported mainly as volatile components from Allium vegetables (including garlic, onions, leeks, chives and scallions) used throughout the world for their sensory characteristics as well as their apparent health benefits. ${ }^{13}$ The sulfur compounds have been reported to have a variety of pharmacological properties. ${ }^{14-18}$ For example, diallyldisulfide and diallyltrisulfide showed antiproliferative and proapoptotic effects in human epithelial cancer and neuronal cell lines, ${ }^{14,15}$ apoptosis in the leukemic HL-60 cell line through activation of caspase- $3^{16}$ and inhibition of NO synthesis in lipopolysaccharideactivated macrophages. ${ }^{17}$

\section{ACKNOWLEDGEMENTS}

This work was supported by the Basic Science Research Program through the National Research Foundation of Korea (NRF) funded by the Ministry of Education, Science and Technology (2012R1A5A2A28671860).

1 Cho, D. H. Mushrooms and Poisonous Fungi in Korea 365 (Iljinsa: Seoul, 2009).

2 Song, J., Manir, M. M. \& Moon, S. S. Cytotoxic grifolin derivatives isolated from the wild mushroom Boletus pseudocalopus (Basidiomycetes). Chem. Biodivers. 6, 1435-1442 (2009).

3 Kim, K. H., Choi, S. U. \& Lee, K. R. Three new fatty acid esters from the mushroom Boletus pseudocalopus. Lipids 47, 593-599 (2012).

4 Kawamura, S., Horii, T., Nakabayashi, T., Abe, Y. \& Chubachi, M. NMR and mass spectral studies of miscellaneous hydrodisulfides. Annual Report of the Radiation Center of Osaka Prefecture 20, 109-114 (1979).

5 Duquesnoy, E., Castola, V. \& Casanova, J. Identification and quantitative determination of carbohydrates in ethanolic extracts of two conifers using ${ }^{13} \mathrm{C}$ NMR spectroscopy. Carbohydr. Res. 343, 893-902 (2008).

6 Ding, Z. G. et al. ${ }^{1} \mathrm{H}$ and ${ }^{13} \mathrm{C}$ NMR assignments of eight nitrogen containing compounds from Nocardia alba sp.nov (YIM 30243T). Magn. Reson. Chem. 47, 366-370 (2009).

7 Jones, I. C., Sharman, G. J. \& Pidgeon, J. ${ }^{1} \mathrm{H}$ and ${ }^{13} \mathrm{C}$ NMR data to aid the identification and quantification of residual solvents by NMR spectroscopy. Magn. Reson. Chem. 43, 497-509 (2005).

8 Eggert, H. \& Djerassi, C. Carbon-13 nuclear magnetic resonance spectra of acyclic aliphatic amines. J. Am. Chem. Soc. 95, 3710-3718 (1973).

9 Freeman, F. \& Angeletakis, C. N. ${ }^{13} \mathrm{C}$ NMR chemical shifts of thiols, sulfinic acids sulfinyl chlorides, sulfonic acids and sulfonic anhydrides. Org. Magn. Reson 21 86-93 (1983).

10 Kameoka, H. \& Hashimoto, S. Two sulfur constituents from Allium schoenoprasum. Phytochemistry 22, 294-295 (1983).

11 Skehan, P. et al. New colorimetric cytotoxicity assay for anticancer-drug screening. J. Natl. Cancer Inst. 82, 1107-1112 (1990).

$12 \mathrm{Kim}, \mathrm{K} . \mathrm{H}$. et al. 4-Methylthio-butanyl derivatives from the seeds of Raphanus sativus and their biological evaluation on anti-inflammatory and antitumor activities. J. Ethnopharmacol. 151, 503-508 (2014).

13 Merhi, F., Auger, J., Rendu, F. \& Bauvois, B. Allium compounds, dipropyl and dimethyl thiosulfinates as antiproliferative and differentiating agents of human acute myeloid leukemia cell lines. Biologics 2, 885-895 (2008).

14 Sundaram, S. G. \& Milner, J. A. Diallyl disulfide inhibits the proliferation of human tumor cells in culture. Biochim. Biophys. Acta 1315, 15-20 (1996).

15 Pinto, J. T. \& Rivlin, R. S. Antiproliferative effects of allium derivatives from garlic. J. Nutr. 131, 1058S-1060S (2001).

16 Kwon, K. B. et al. Induction of apoptosis by diallyl disulfi de through activation of caspase-3 in human leukemia HL-60 cells. Biochem. Pharmacol. 63, 41-47 (2002).

17 Ippoushi, K., Itou, H., Azuma, K. \& Higashio, H. Effect of naturally occurring organosulfur compounds on nitric oxide production in lipopolysaccharide-activated macrophages. Life Sci. 71, 411-419 (2002).

18 Park, H. S., Kim, C. \& Park, M. S. Discovery and synthesis of novel allylthioaralkylthiopyridazines: their antiproliferative activity against MCF-7 and Hep3B cells. Arch. Pharm. Res. (e-pub ahead of print 14 June 2014; doi:10.1007/s12272-014-0416-3). 